\title{
Skin Response Sequence Number
}

National Cancer Institute

\section{Source}

National Cancer Institute. Skin Response Sequence Number. NCI Thesaurus. Code C117670.

An identifier that describes the relative position of skin response data within a series. 